\title{
A Review on Development and Standardization of Metering Mechanism for Automatic Turmeric Planter
}

\author{
D. V. Nimbalkar* and S. M. Nalawade \\ Department of Farm Machinery and Power Engineering, Dr. A.S.C.A.E. \& T., \\ MPKV, Rahuri, India \\ *Corresponding author
}

Keywords

automation in Agriculture, smart farming, , Turmeric planter, Automatic Planter

Article Info

Accepted: 22 April 2021 Available Online: 10 May 2021
Turmeric planting is a laborious and time consuming field operation when performed manually. The semi-automatic Turmeric planters are operate due to limitations on manual feeding rates of finger which vary with respect to work duration and skill of the operator. Automation in the field of Turmeric planters has provided opportunities for savings in labour and time required for planting operation in open field and controlled environmental structures. The advent and recent advances in planting technologies suggest ample scope of working on automated Finger pickup and drop mechanisms. Use of finger pickup mechanism in automatic planters can repeatedly extract single finger automatically from the finger hopper with the help of a forks and drop at predefined location. In general, these systems comprise either a machine vision system for extracting the finger; a finger removal device with ejector; or a pick-up system, feeding system and a planting system. Such automated systems have helped ease the planting operation and efficient planting by maintaining the accuracy, precision and effectiveness in planting finger with minimum human intervention. This study highlights the research gaps and developments in smart planting technologies used in the field of Turmeric cultivation.

\section{Introduction}

Turmeric is considered as one of the important food items of Indian diet without which any meal is incomplete. Due to this need, the cultivation and production of Turmeric are increasing day-by-day. India produces nearly $94 \%$ of the total turmeric production in the world and it enjoys nearly $50 \%$ of the global market. 


\section{Area, Production and Importance}

It is widely cultivated in the countries such as India, Pakistan, Bangladesh and China, which form the important producing countries in the world. Turmeric was cultivated over an area of $1,93,395$ ha in India with a production of 10 , 51160 tons during 2016-17. India is the leading producer and supplier of turmeric in the world. During 2000-01 the export of turmeric was 44,627 tonnes and was increased to 51500 tonnes in 2006-07. However export earnings have increased from Rs. 11558 Lakhs in 2000-01 to Rs.16480 Lakhs in 2006-07. The UAE, Bangladesh, Srilanka, USA and Japan are the major markets for Indian turmeric. India enjoys a monopoly position with a share of $90 \%$ in the International trade for turmeric (Sakamma 2009). Maharashtra and Tamil Nadu were second and third in the ranking 2018 year. Volume of turmeric produced across India in financial year 2018, by state Telangana 294.56, Maharashtra 190.09, Tamil Nadu 116, Gujarat 78.91 (in 1,000 metric tons), (Source APEDA 2018 data).

\section{Utility of turmeric and its nutritive Value}

Turmeric is a flowering plant, Curcuma longa of the ginger family, the roots of which are used in cooking. The plant is a perennial, rhizomatous, herbaceous plant native to the Indian subcontinent and Southeast Asia, that requires temperatures between 20 and $30{ }^{\circ} \mathrm{C}$, $\left(68\right.$ and $86{ }^{\circ} \mathrm{F}$ ) and a considerable amount of annual rainfall to thrive. Plants are gathered each year for their rhizomes, some for propagation in the following season and some for consumption.

It has to support almost $17 \%$ of world population from $2.3 \%$ of world geographical area and $4.2 \%$ of world's water resources. The present cropping intensity of $137 \%$ has registered an increase of only $26 \%$ since 1950 -
51. Volume of turmeric produced across India in financial year 2018, by Telangana 294.56, Maharashtra 190.09, Tamil Nadu 116, Gujarat 78.91 (in 1,000 metric tons), (APEDA, 2018).

Turmeric is being propogated by rhizomes may be mother or fingers. The rhizomes should be treated with the 0.3 per cent Agallol or Dithane M-45 solution for 30 minutes and then dried in the shade before planting. Turmeric rhizomes are planted in the furrows by dibbling at a spacing of $30 \times 30 \mathrm{~cm}$, and 15 $x 15 \mathrm{~cm}$. After dibbling the rhizomes are covered with the loose soil from the ridge.

\section{Importance and need of the planting}

The production and productivity of turmeric in India are very low compared to many other countries. Ignorance of farmers about improved varieties, climate, soil and agrotechniques, diseases and pest damaging the crops and their control measures as well as post-harvest management are though main reasons, inadequate market support is also responsible for limiting the production and productivity indirectly.

Different bed planting configurations are used throughout the world depending on soil type, available machinery, farmer's preference and expertise. In general, increasing the width of the bed reduces total water used and increases land use efficiency and yield by reducing the uncropped furrow area.

At present there is a great demand for this crop in both local and international markets. Production and total planting areas have been maintained constantly while the export value has been increasing every year. The increasing demand both of home uses and industries has resulted in step rise in Turmeric prizes.

Manual planting of turmeric is both labors intensive and costly, resulting in various 
problems for farmers. The capacity of man is very low about 0.05 ha./man/day and payment for planting is 11.9 per cent of total cost of production (Jarudchai, 2002). Because of the high costs of the traditional methods of turmeric planting, cultivation and harvesting which is very time consuming and labor intensive, its large scale production is not economical and is therefore very limited.

This research, therefore, concerns the need to improve the precision of the turmeric planter, which directly affects the yield, and the farmer's acceptance. The specific objectives of this research is to develop and emetering mechanism for automatic turmeric planter, which is capable of singulating turmeric fingers and planting at predetermined depth and plant spacing on raised bed

\section{The following are the three different types of seed sowing}

\section{Broadcasting}

A field is initially prepared with a plough to a series of linear cuts known as furrows. The field is then seeded by throwing the seeds over the field, a method known as manual broadcasting.

The result was a field planted roughly in rows, but having a large number of plants. When the seeds are scattered randomly with the help of hand on the soil, the method is called broadcasting.

\section{Dibbling}

Drill sowing and dribbling (making small holes in the ground for seeds) are better method of sowing the seeds. Once the seeds are put in the holes, they are then covered with the soil. This saves time and labour and prevents the damage of seeds by birds.

\section{Precision planting}

Precision planting is the method of accurate placing of single seeds at about equal intervals in rows and Hill dropping is placing groups of seeds at about equal intervals in rows.

Another method of sowing the seeds is with the help of a simple device consisting of bamboo tube with a funnel on it attached to a plough. As the plough moves over the field the tube attached to it leaves the seeds kept in the funnel at proper spacing and depth. The plough keeps making furrows in the soil in which the seeds are dropped by the seed drill.

Kumar and Gill (2010) conducted an experiment to evaluate the effect of planting method, plant density and planting material on growth, yield and quality of turmeric (Curcuma longa). The experiment consisted of two planting methods (flat and ridge), three plant densities $(1,66,667 ; 1,11,111$ and 83,333 plants $\mathrm{ha}^{-1}$ ) and three types of planting material (mother, primary and secondary rhizomes).Fresh rhizome resulted in an yield of 164.8 and $160.3 \mathrm{q} \mathrm{ha}^{-1}$ will produced in flat and ridge method of planting but the differences were non-significant. Whereas, planting of mother rhizomes produced highest yield (207.7 q ha ${ }^{-1}$ ), turmeric yield compared to primary and secondary rhizomes and it decreased significantly with decrease in seed size.

Meandered $a l$, (2013) conducted experiment to study the effect of seed rhizome size and plant spacing on growth, yield and quality of ginger with three seed rhizome sizes viz., $20 \mathrm{~g}$, $30 \mathrm{~g}$ and $40 \mathrm{~g}$ and five plant spacing viz., 25 $\mathrm{cm} \times 15 \mathrm{~cm}, 25 \mathrm{~cm} \times 25 \mathrm{~cm}, 30 \mathrm{~cm} \times 20 \mathrm{~cm}$, $30 \mathrm{~cm} \times 30 \mathrm{~cm}$ and $40 \mathrm{~cm} \times 20 \mathrm{~cm}$. They reported that the rhizome size of $40 \mathrm{~g}$ took least number of days to first sprouting of rhizome(12.73) followed by 30g. Similarly plant height at harvest $67.87 \mathrm{~cm}$, Number of 
tillers per plant 11.51and leaf area index 3.59, yield 27.41 tha ${ }^{-1}$, essential oil content 1.83 per cent and starch content 30.27 percent were recorded maximum with $40 \mathrm{~g}$ seed rhizome size. Regarding plant spacing highest plant height $65.07 \mathrm{~cm}$, leaf area index 5.25 and yield 26.40 tha $^{-1}$ will recorded from closest plant spacing of $25 \mathrm{~cm} \times 15 \mathrm{~cm}$. The most satisfactory rhizome yield $38.06 \mathrm{t} \mathrm{ha}^{-1}$ will found from the treatment combination of $40 \mathrm{~g}$ seed rhizome size with $25 \mathrm{~cm} \times 15 \mathrm{~cm}$ plant space.

\section{Historical review of turmeric planting}

Angles (2015) studied that the performance of turmeric were examined in terms of area, production and productivity in important states of south India viz. Andhra Pradesh, Tamil Nadu, Karnataka and Kerala. These states contributed around 80 percent of turmeric produced in India. Secondary data will used for the study, considering the period from 1979-80 to 1998-99. Exponential form of growth function will used for the analysis. All the states registered significant growth in area, production and productivity except area in case of Tamil Nadu and Kerala, production in Tamil Nadu and productivity in Karnataka. Evolving location specific varieties, adaptation of modern cultural practices and intensive cultivation were some of the suggestions for enhancing productivity of turmeric.

Yadav (2017) reported that it is member of 'Zingiberaceae family' Curcuma Longa, Linn, well known as Turmeric, is a perennial, erect and leafy plant with very large, lily like leave up to $1.2 \mathrm{~m}$ long. It has oblong, pointed leaves and funnel-shaped yellow flowers. The rhizome, the portion of the plant used medicinally, is usually boiled, cleaned, and dried, yielding a yellow powder. Dried Curcuma longa is the source of the spice turmeric, the ingredient that gives curry powder its characteristic yellow colour.
Turmeric is used extensively in foods for its flavour and colour, as well as having a long tradition of use in the Chinese and Ayurveda systems of medicine; India has a rich history of using plants for medicinal purposes. b Turmeric (Curcuma longa) is extensively used as a spice, food preservative and colouring material in India. Turmeric is widely consumed in the countries of its origin for a variety of uses, including as a dietary spice, a dietary pigment, and an Indian folk medicine for the treatment of various illnesses. It is used in the textile and pharmaceutical industries and in Hindu religious ceremonies in one form or another. Current traditional Indian medicine uses it for biliary disorders, anorexia, cough, diabetic wounds, hepatic disorders, rheumatism, and sinusitis. The old Hindu texts have described it as an aromatic stimulant and carminative. Powder of turmeric mixed with slaked lime is a household remedy for the treatment of sprains and swelling caused by injury, applied locally over the affected area. Safety evaluation studies indicate that both turmeric and curcumin are well tolerated at a very high dose without any toxic effects. Thus, both turmeric and curcumin have the potential for the development of modern medicine for the treatment of various diseases.

\section{Physical properties for planting like LBT, bulk density, true density, angle of repose, comprehensive strength}

Balasubramanian (2012) studied properties of turmeric rhizome variety. IISR Alleppey Supreme. Sample was divided into three grades (I: $25-35 \mathrm{~mm}$, II: $35-45 \mathrm{~mm}$, III: $45-$ $55 \mathrm{~mm}$ ) according to its major dimension to study its physical properties. The average values of geometric property viz., length $(30.38-50.60 \mathrm{~mm})$, breadth $(9.77-10.64 \mathrm{~mm})$, thickness $(5.18-6.44 \mathrm{~mm})$, arithmetic mean diameter $(15.82-21.91 \mathrm{~mm})$, geometric mean diameter $(12.77-13.76 \mathrm{~mm})$, square mean diameter (24.24-28.58 $\mathrm{mm})$, equivalent diameter (17.61-21.41 mm), sphericity $(0.27-$ 
$0.42)$, aspect ratio $(0.20-0.35)$, unit volume (1641-2901 mm3), surface area (771-1265 $\mathrm{mm} 2)$ and shape factor (1.63-1.77) for grades I, II \& III are reported. The gravimetric property viz., bulk density (260-348 kg/m3), true density (1341-1354 kg/m3) and porosity (74.53-80.93 percent), and frictional property viz., angle of repose (37.57-38.90 $)$ and coefficient of friction with respect to different surface viz., aluminum sheet, mild steel sheet and plywood sheet for grades I, II and III were found to range between of 0.69-0.81, 0.84$0.94,0.80-0.86$, respectively.

Khambalkar (2017) reported that the average length of all variety rhizomes will $58.11 \mathrm{~mm}$; breadth $36.71 \mathrm{~mm}$ and thickness of $30.17 \mathrm{~mm}$ were observed. The average weight of rhizome will found $34.87 \mathrm{gm}$. The average arithmetic mean diameter, square mean diameter, equivalent diameter, geometric mean diameter were calculated $41.66 \mathrm{~mm}$, $70.22 \mathrm{~mm}, 50.57 \mathrm{~mm} \& 39.80 \mathrm{~mm}$.

The average surface area and unit volume were obtained $4370.74 \mathrm{~mm} 2$ and 25261.37 $\mathrm{mm} 3$. The Average of angle of repose, true density \& bulk density such as 18.060, $1018.95 \mathrm{~kg} / \mathrm{m}^{3} \& 529.66 \mathrm{~kg} / \mathrm{m}^{3}$. The average shape factor will calculated 0.03 . The porosity will ranges from 32 to 63 percent respectively. The average sphericity will found $0.71 \mathrm{~mm}$.

Preetham et al., (2018) a field experiment will conducted at Horticultural Research Station, Adilabad (Northern Telangana Zone) of Telangana state for two consecutive years 2016 and 2017 to find out the performance of Salem variety of turmeric with two planting materials (Split and full rhizome) and three population levels $(1,48,148,74,074$ and 98,765 plants $\mathrm{ha}^{-1}$ ) on raised beds. The two years study revealed that full rhizomes used as planting material showed significantly higher mean plant height of $34.20,58.47,80.61$ and $82.68 \mathrm{~cm}$ at $60,90,120$ and 150 DAP respectively. Full rhizome treatment showed significantly higher number of mother rhizomes (3.86), primary fingers (12.54), secondary fingers plant $^{1}{ }^{1}$ (15.98), clump weight plant- $^{1}(1035 \mathrm{~g})$, girth of mother rhizome $(19.13 \mathrm{~cm})$, weight of mother rhizome $(86.18 \mathrm{~g})$ and fresh rhizome yield $\left(21.58 \mathrm{tha}^{-1}\right)$ over split rhizome treatment.

Plant population densities did not differ significantly for plant height and number of leaves plant-1 during all growth stages during both the years of study. Maximum number of mother rhizomes (3.97), primary fingers (13.05), secondary fingers (16.94), clump weight plant ${ }^{-1}(1140 \mathrm{~g})$, girth of mother rhizome $(21.60 \mathrm{~cm})$ and weight of mother rhizome $(87.65 \mathrm{~g})$ were recorded in 74,074 plant population treatment. Maximum fresh rhizome yield (20.14 t ha-1) will recorded with plant population stand of 1,48,148 plants $\mathrm{ha}^{-1}$ which will on par with plant population stand of 98,765 and 74,074 plants ha ${ }^{-1}$.

\section{Moisture content}

Athmaselvi and Varadharaju (2002) reported the moisture content of the turmeric varieties. The average moisture content of the variety BSR-1 and Erode local will82 percent (wb) and the moisture content of BSR-2 will 86 percent (wb) immediately after harvest.

\section{Size}

Ajav and Ogunlade (2014) studied some physical properties of ginger rhizomes and they reported the average values of major, minor and intermediate diameters, geometric mean, spherecity, bulk volume and surface area are $112 \mathrm{~mm}, 38.3 \mathrm{~mm}, 72.3 \mathrm{~mm}, 67.6 \mathrm{~mm}$, $0.61,832.5 \mathrm{~cm}^{3}$ and $147 \mathrm{~cm}^{2}$.

Subhashini et al., (2015) studied the physical properties of turmeric rhizomes were determined at different moisture contents such 
as 8,12 and 16 per cent. They reported that the bulk density and true density of turmeric rhizome at 12 percent Moisture content were $647.5 \mathrm{kgm}^{-3}$ and1303.3 $\mathrm{kgm}^{-3}$ respectively. The porosity of turmeric rhizomes will found to be 67.3 percent.

\section{Bulk Density}

The mass per unit bulk volume of a substance under some specified conditions such as temperature, moisture content etc., is called bulk density.

Mishra and Kulkarni (2009) found out the bulk density of turmeric rhizomes (varietySangli). The average bulk density of fresh turmeric rhizome at 12.4 percent $(\mathrm{db})$ moisture content was $622.33 \mathrm{kgm}^{-3}$.

Ajav and Ogunlade (2014) found out the average bulk density of ginger rhizomes. The average bulk density of fresh ginger rhizome at 10.9 percent and 51.6 percent $(\mathrm{db})$ moisture content was $0.92 \mathrm{gcm}^{-3}$.

\section{Frictional properties}

The frictional properties such as coefficient of friction and angle of repose are important in the design of hoppers, conveying system, threshers etc. (Sahayand Singh, 1994). Frictional properties help to understand the behavior of the given material motion on different surfaces.

\section{Angle of repose}

The angle of repose is the angle between the base and the slope of the conformed on a free vertical fall of granular materials over a horizontal plane. The size, shape, moisture content and orientation of the grains affect the angle of repose (Sahayand Singh, 1994). Mishra and Kulkarni (2009) identified the angle of repose of fresh turmeric rhizome, by using a bottomless cylinder placed on a flat surface and filled it with turmeric rhizomes. The cylinder will rise slowly allowing the rhizomes to flow and assume a natural slope in the form of cone. The diameter and height of cone will measured and angle of repose calculated. The angle of repose for fresh turmeric rhizome will $33^{\circ}$.

Ajav and Ogunlade (2014) reported that the angle of repose of fresh ginger rhizomes measured by using a specially constructed topless and bottomless box made of plywood, with are movable front panel will $48^{\circ}$.

\section{Coefficient of friction}

The coefficient of friction between granular material is equal to the tangent of the angle of internal friction for the material. The frictional coefficient depends on grain shape, surface characteristics and moisture content. Athmaselvi and Varadharaju(2002) studied the static coefficient of friction of turmeric rhizomes of BSR-1, BSR-2and Erode varieties with respect to moisture content on four metallic surfaces viz., aluminum, mild steel, galvanized iron and stainless steel. The static coefficient of friction increased with increase in moisture content of rhizomes in all metal surfaces. Jayashree (2009) reported the coefficient of friction of ginger rhizomes. The coefficient of friction of fresh ginger rhizomes at a moisture content of 81.70 percent (wb) against ply wood, stainless steel, aluminum, galvanized iron and mild steel surfaces will $0.53,0.57,0.68,0.72$ and 0.74 , respectively.

\section{Various metering mechanisms for Turmeric Planters}

The metering mechanisms must work effectively in order to continuously meter seeds at a uniform rate and spacing with respect to the ground surface at travelling speed. Besides, the metering mechanism 
should meter the seeds with minimum damage. However, the metering mechanism parameters that affect the performance are discussed in the subsequent sections

Mathanker and Mathew (2002) stated that picker wheel type and horizontal disk cell type metering mechanisms perform well under suitable working conditions. The planting mechanisms were tested at various linear (peripheral) speeds. The percentage of cell filled varies from 128 to 143 per cent, physical damage from 6.5 to 16 per cent and missing cells percentage from 12 to 14.2 percent as the linear speed varied from 5.5 to $18.1 \mathrm{~m} \mathrm{~min}^{-1}$ respectively for the picker wheel type metering mechanism. For the horizontal disc cell type metering mechanism percent cell filled varies from 80 to 99 per cent and percentage of physical damage from 1 to 3 per cent as the linear speed varied from 5.1 to 21.7 $\mathrm{m} \min ^{-1}$ respectively. Hence, picking wheel mechanism will found suitable for automatic ginger planters with optimum linear speed in the range of 10 to $12 \mathrm{~m} \mathrm{~min}^{-1}$ and horizontal disc cell mechanism will found suitable for semi-automatic ginger planters with optimum linear speed range of 5 to $8 \mathrm{~m} \mathrm{~min}^{-1}$.

Kazmeinkhah, et al., (2007) designed a semiautomatic Transplanter machine, in order to cultivate sugar beet seedling. This machine will able to cultivate seedling with the row distance of $65 \mathrm{~cm}$, seedling distance of 50.3 $\mathrm{cm}$ and $13 \mathrm{~cm}$ depth. Standard deviation in comparison to the desired position will 4.5 percent along the cultivation row line and 3.6 percent perpendicular to the cultivation row line.

Jayanand Kumar (2004) investigated the design of planter in relation to the physical properties of seeds. They reported that in the absence of devices for the positive removal of seeds from the cells of the plate, seeds drop by gravity and as the peanut seeds are non- spherical, they move slowly leading to the variation in seed spacing. In order to achieve the uniformity in seed spacing and accuracy in seed rate, it is essential to use the metering plate with size of cells matching the size of seeds.

Sahoo and Srivastava (2008) investigated the seed pattern characteristics of soaked okra seed with different metering systems viz., vertical roller, horizontal plate, horizontal plate (edge drop), inclined plate, cell size viz., maximum seed dimension, 10 per cent more than maximum seed dimension, 25 per cent more than maximum seed dimension and cell speed viz., 10,14,18, $24 \mathrm{rpm}$. They concluded that the average spacing will close to theoretical spacing for vertical roller, horizontal plate, horizontal plate (edge drop) with cell size 10 per cent more than the maximum seed dimensions. But in case of inclined plate the average spacing will close to theoretical spacing with the cell size equal to maximum seed dimensions. The quality of feed index will influenced highly by the metering systems, cell size and cell speed. The quality of feed index decreased with increase in speed. However, with increase in cell speed to $14 \mathrm{rpm}$ only 5 percent decrease of quality of feed index will observed. The cell speed mostly influenced the multiple index, miss index and degree of variation. The metering system influenced the seed damage the most followed by cell speed. Incline plate metering system will found the best for planting soaked okra seed.

Vasuki (2012) designed and developed a tractor operated turmeric planter and it consist of belt type metering mechanism for ridger bottom, rhizome hopper, cup feed rhizome metering mechanism, mainframe, shoe type furrow opener, ground wheel and chain sprocket power transmission drive. The turmeric rhizome planter will evaluated in the laboratory for its performance. The 
performance indices viz., singles, doubles, triples and missing index of turmeric planter were $67.9,12.55,3.52$, and 15.95 percent respectively. The mean and standard deviation of rhizome spacing in the laboratory tests were $28.95 \mathrm{~cm}$ and $9.73 \mathrm{~cm}$, respectively. The tractor operated turmeric planter will tested in the field for performance at an optimized speed of $1.5 \mathrm{~km} \mathrm{~h}^{-1}$. The average plant to plant spacing will $22.68 \mathrm{~cm}$ after 30 DAP. The field capacity of the turmeric planter was 0.27 ha $^{-}$ 1. The total time required for the planting operation will $5.78 \mathrm{hr} \mathrm{ha}$ with a field efficiency of 64.28 percent. The seed rate will reduced to $1027 \mathrm{kgha}^{-1}$ bythe developed planter.

The planter will designed, fabricated and using a conveyor type metering mechanisms and tested in the Agricultural and Bio resources Department of The Federal University of Technology, Mina. The performance tests of the fabricated machine were carried out using three levels of turmeric rhizome lengths $(30 \mathrm{~mm}, 45 \mathrm{~mm}$ and $60 \mathrm{~mm}$ ) at three levels of operational speeds $(8 \mathrm{~km} / \mathrm{h}$ $10 \mathrm{~km} / \mathrm{h}$ and $12 \mathrm{~km} / \mathrm{h}$ ). The highest percentage turmeric rhizome miss index of 35 per cent will recorded for turmeric rhizome length of $30 \mathrm{~cm}$ at machine operational speed of $10 \mathrm{~km} / \mathrm{h}$ whereas the lowest percentage turmeric rhizome miss index of 15 per cent will obtained for turmeric rhizome length of $60 \mathrm{~cm}$ at the machine operational speed of $12 \mathrm{~km} / \mathrm{h}$. The highest capacity of $0.96 \mathrm{ha} / \mathrm{h}$ will recorded at the highest operational speed of $12 \mathrm{~km} / \mathrm{h}$. The lowest field capacity of $0.63 \mathrm{ha} / \mathrm{h}$ will recorded at the lowest machine speed of $8 \mathrm{~km} / \mathrm{h}$ (Gbabo, 2020).

Richy et al., (1961) described the inclined plate type metering device. It will be a variation of a cup feed. An inclined seed plate with indented cells in the edge dipped in a wall of seed fed under a baffle plate from the hopper, lifted the seeds and dropped them into a delivery tube. This type of feed, like a cup feed, required no cut off which sometimes might cause seed injury but it might be affected by hopper tilt and rough ground. This type of metering mechanism will used in some vegetable planters. Speed of rotation will required to be slow to avoid centrifugal force, which would throw the seeds from the cells prematurely. Some planters used two plates dropping alternately into one seed tube for more capacity.

Roharbach et al., (1969) developed a stochastic model for system designed to produce uniform spacing of planted seed as a consequence to statistically characterize the plant spacing produced by these system using horizontal plate seed metering mechanism. Number of seed that occupied a seed cell at the time of discharge, the drop error and the survival factor were also studied.

Ryu and Kim (1998) designed roller type metering device for precision planting. The design parameters affecting the uniformity of seed placements were investigated from the geometry of roller and brush and the roller will designed accordingly. Experimental results showed that the designed metering roller made a better performance of seed placement than that made by the previous one. The method could also be applied to the design of metering devices for precision hill dropping of other crops.

Wanjura and Hudspeth (1969) recommended that the metering device on a seeder should be located as low as possible so that seed should fall freely to the bottom of soil trench.

Kepner et al., (1987) reported that metering of tuber and seed flow has two aspects. The first is the metering rate, which refers to the number of seeds that are released from the hopper per unit time. Metering rate is an important parameter for any planter to achieve 
desired plant population. The second is that, seeds must be dropped through the seed tubes to achieve a uniform spacing of seed placement in each row.

Kepner et al., (1987) reported automatic potato planters have vertical, rotating picker wheels with devices to either pierce or grip individual seed pieces and then drop them into the furrow. The picker pin type is the most common type of mechanism. Each arm or head of the picker wheel had two sharp picking pins that pierce a seed piece in the picking chamber carry it over to the front, and then release it above the furrow. The position of the picker pins on each head is adjustable to accommodate various sizes of seed pieces. The spacing of seed pieces in the row is controlled by the speed ratio between the ground wheels and the picker wheels.

Kachman and Smith (1995) reported that the spacing of the seeds are affected where the mechanism fails to select or drop a seed resulting in large spacing between seeds; or because the mechanisms elects and drops multiple seeds causing small spacing between seeds. To achieve accurate seed spacing, different parameters that affect the placement need to be optimized for a specific size of seed viz., shape of the seed hole on the disc for singulation of seed, speed of the disc to regulate seed spacing and vacuum pressure required to hold, transport and drop the seed.

Srivastava (2008) evaluated four different types of metering systems on the basis of their performance parameters i.e. average spacing, quality of feed index, multiple index, miss index, degree of variation and seed damage for metering soaked okra seed at three levels of cell size and four levels of cell speed. The average spacing observed will close to the theoretical spacing for cell size equal to maximum seed dimension. The quality of feed index will influenced highly by metering systems, cell size and cell speed. The metering systems influenced the seed damage the most followed by cell size. It will concluded that inclined plate metering system will best suited for metering soaked okra seed.

Gbabo (2020) Planting of turmeric has been a challenge to the farmers in Nigeria due to the absence of planting machine. The performance tests of the fabricated machine were carried out using three levels of turmeric rhizome lengths $(30 \mathrm{~mm}, 45 \mathrm{~mm}$ and $60 \mathrm{~mm})$ at three levels of operational speeds $(8 \mathrm{~km} / \mathrm{h} 10 \mathrm{~km} / \mathrm{h}$ and $12 \mathrm{~km} / \mathrm{h}$ ). The results revealed that there will no steady pattern in the increase or decrease of miss index with increase in turmeric rhizome length and machine operational speed. The highest percentage turmeric rhizome miss index of 35 per cent will recorded for turmeric rhizome length of $30 \mathrm{~cm}$ at machine operational speed of $10 \mathrm{~km} / \mathrm{h}$ whereas the lowest percentage turmeric rhizome miss index of 15 per cent will obtained for turmeric rhizome length of $60 \mathrm{~cm}$ at the machine operational speed of $12 \mathrm{~km} / \mathrm{h}$.

The machine operational speed and size of the turmeric rhizomes affect the field capacity of the machine. The highest capacity of $0.96 \mathrm{ha} / \mathrm{h}$ will recorded at the highest operational speed of $12 \mathrm{~km} / \mathrm{h}$. The lowest field capacity of $0.63 \mathrm{ha} / \mathrm{h}$ will recorded at the lowest machine speed of $8 \mathrm{~km} / \mathrm{h}$. The developed machine could reduce drudgery involved in manual turmeric planting and save about substantial amount of labour and operating time.

\section{Furrow openers for planters}

Chaudhuri (2011) evaluated the performance evaluation of various types of furrow openers for seed drill. The results stated that increase in rake angle increased the draught and vertical force acting on the furrow opener. The values of the rake angle for the lowest draught are usually around $25^{\circ}$ to $30^{\circ}$. Increase in the 
width of furrow opener increases draught and reduces the amount of soil covering the seed in the furrow. Disc type furrow openers are generally satisfactory for conventional tillage due to lower draught, less soil disturbance and less variation in depth. Hoe-type furrow openers place seed close to the furrow bottom and create more soild is turbance which increase the soil moisture loss from the furrow.

The best performance under zero tillage condition will given by the chisel, winged chisel, inverted-T and winged type furrow openers. Runner type furrow openers are suitable for sowing under conventional tillage system only for shallow sowing under irrigated conditions. Winged, inverted-T and hoe-type furrow openers are suitable for seed cum fertilizer drills.

\section{Design factors affecting the planter performance}

Buitenwerf et al., (2006) reported that the accuracy of planting (distance in the seeding furrow) is influenced for a large part by the cup-belt unit of the potato planter.

A more regular shape (lower shape factor) does not automatically result in a higher accuracy. A sphere (golf ball) in most cases will deposited with a lower accuracy than a potato. This will caused by the shapes of the guiding duct and cups. Jiraporn et al., (2010) conducted experiments to optimize the height of seed delivery tube above ground level for 10 row tractor operated garlic planter. They observed that the height of the seed delivery tube at $30 \mathrm{~cm}$ above ground level provides the lowest variation of $25 \mathrm{~mm}$, from the line of motion at a forward speed $1.67 \mathrm{~km} \mathrm{~h}^{-1}$.

\section{Operational speed parameters}

Hamad and Banna (1980) and Amin (1983) showed that the length of feeding -wheel mechanism speed and transmission rotor has positive effect on the amount of sowing rate. There is also a good deal of variation between different machines in the accuracy of spacing, depending on whether there is appreciable wheel slip and on whether the potatoes are allowed to role in the furrow bottom. Generally, the forward speed of this type of machinery is not over3.2 $\mathrm{kmh}^{-1}$.

Ismail (1989) stated that the operational speed of manual filling of buckets of metering mechanism in planting machine at is very low and in the range from 1.5 to $1.6 \mathrm{kmh}^{-1}(0.4$ to $\left.0.44 \mathrm{msec}^{-1}\right)$. He stated that the time span necessary for the operation of taking out potato seed from the box and placing it into the bucket amounts to approximately0.75 seconds.

Field performance of various methods, comparative studies

Anonymous (1986) the Ludhiana Research Center developed a tractor operated ridger planter with an inclined plate metering mechanism, ground wheel and provision for shifting the position of the furrow opener. Its field capacity will 0.2 to $0.33 \mathrm{ha} / \mathrm{hr}$ at forward speed of 2 to $2.5 \mathrm{~km} / \mathrm{hr}$.

Griepentrog (1998) states that quality of horizontal and vertical distribution of seeds is influenced by row spacing, sowing depth, soil conditions, seeder design, seed density and operator skill. The mean spacing $(\mathrm{X})$, the standard deviation of the spacing between plants (SD) and the coefficient of variation (CV) are commonly used for describing seed spacing uniformity. The mean spacing is influenced by seed or plant density and longitudinal distribution. For common grain drills, a CV of 20 per cent is an acceptable accuracy achieved by mechanical and pneumatic machines when they are performing well. 
Misener (1979) evaluated the cup and pick type potato planters. Co-efficient of variation in spacing, number of seeds fill and number of seed piece skips were determined for each planter. In general, the pick type planter will slightly more effective than the cup type planter. The co-efficient of variation of spacing for the cup and pick type planters ranged from 59.2 to 87.1 and from 55.3 to 68.7 , respectively. The average number of doubles per $30.5 \mathrm{~m}$ of row length ranged from 5 (6.2 percent of seed pieces) to 65 (33.6 percent) for the cup type and from 5 (6.8 percent) to 52 (29.0 per cent) for the pick type planter over various forward speeds and nominal spacing's. The range of skips for the cup planter will 3(3.2percent) to 22(14.7 percent) and for the pick type planter, varied from3(3.0 percent) to 19 (12.1 percent) per $30.5 \mathrm{~m}$ of row length.

Panning et al., (2000) evaluated sugar beet planting performance for a precision planter designed for shallow planting of small seeds, a general purpose planter designed for row crops, and a vacuum metering general purpose planter designed furrow crops that will equipped with three seed tube designs.

In their field study, the most uniform seed spacing for each planter configuration occurred at the lowest speed of $3.2 \mathrm{kmh}^{-1}$. For all planter configurations, the seed spacing uniformity decreased as the forward speed increased from 3.2 to $8.0 \mathrm{~km} \mathrm{~h}^{-1}$. Seed spacing uniformity determined in laboratory tests will greater than, or equal to, seed spacing uniformity determined in field test.

Mari et al., (2002) carried out an experiment to evaluate the performance of potato planter. The planter will powered by Fiat-480 diesel tractor at low $3^{\text {rd }}$ gear speed. The performance of tractor planter determined were moisture content of 15.73 percent, fuel consumption will $24.04 l \mathrm{~h}^{-1}$, the travel reduction will 5.04 per cent, field efficiency will 67.47 percent, field capacity will $0.80 \mathrm{hah}^{-1}$.

Al-Gaadi and Marey (2011) evaluated the effect of forward speed and tuber characteristics on tuber spacing for a cup belt potato planter. They had selected the three level of forward speeds $(1.8,2.25$ and $3 \mathrm{~km} \mathrm{~h}$ ${ }^{1}$ ) and three tuber sizes ( 35 to 45,45 to 55 and 55 to $65 \mathrm{~mm}$ ) the performance of the planter will evaluated in terms of mean tuber spacing $(\mathrm{M})$, the coefficient of variation (CV), the multiple index(MULTI), the miss index (MISI). Tuber sizes of 35 to $45 \mathrm{~mm}$ resulted better tuber spacing uniformity than other tested tuber sizes. Forward speed of $2.25 \mathrm{~km}$ $\mathrm{h}^{-1}$ had maximum efficiency and does not affect the seed tuber uniformity.

Al-Gaadi (2011) investigated the performance of an auto feed cup-belt potato planter under different operating conditions with different tuber shapes for whole and cut tubers. He concluded that the coefficient of variation and missing index were proportional to the forward speed, and inversely proportional to the gate height and speed ratio. The highest $\mathrm{CV}$ (coefficient of variation) and MISI(missing index) values were 68.4 percent and 16.42 percent respectively for cut tubers at $3 \mathrm{~km} \mathrm{~h}^{-1}$ travel speed at a speed ratio of 1.22 and $80 \mathrm{~mm}$ gate height. The lower multi index values were observed in the cut tubers and the maximum multi value of 7.76 percent will observed in the whole tubers.

Dixit et al., (2015) conducted the performance evaluation of tractor mounted vertical belt type paired row potato planter for planting potato variety KufriJyotion beds in controlled traffic. The field capacity of the paired row planter wills $0.24 \mathrm{ha} \mathrm{h}^{-1}$ at an average forward speed of $2.5 \mathrm{~km} \mathrm{~h}^{-1}$. Missing, multiples and seed damage for paired row planter will 3.3, 1.5 and 1.5 percent, respectively, whereas in case of automatic planter, it will 5.0, 1.8 and 10.0 percent, respectively. 
Fig.1 Various parameters involved in seeding

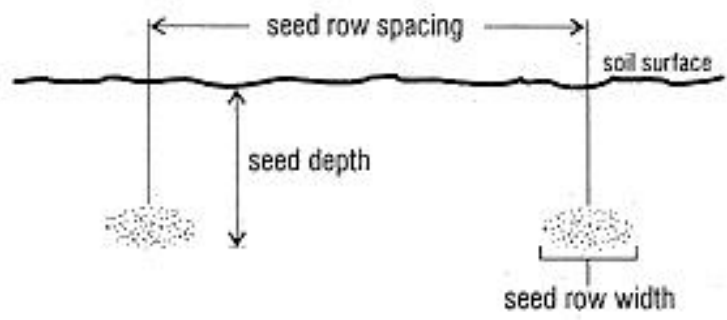

Fig.2

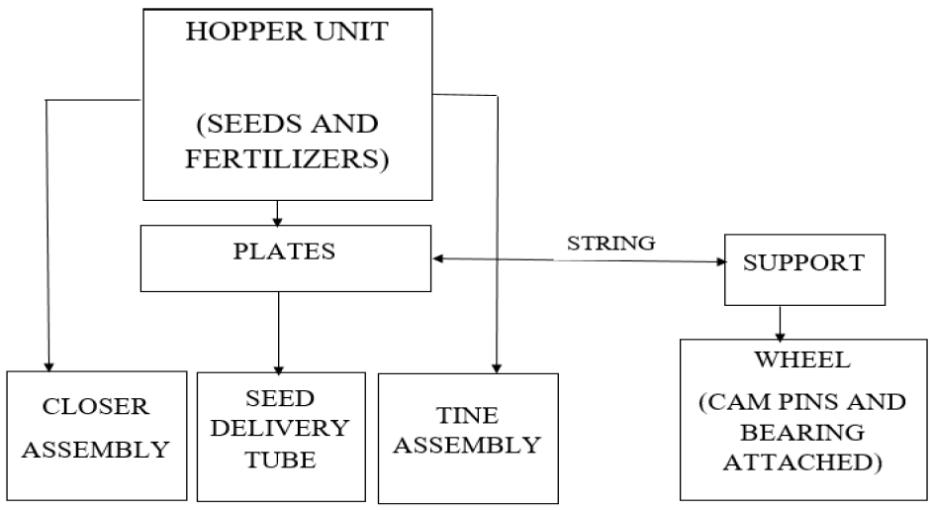

Fig.3

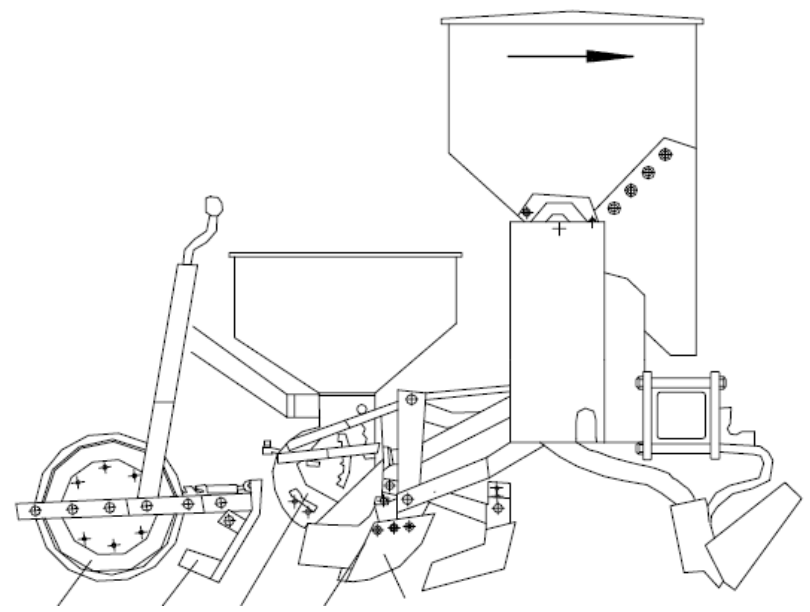


Fig.4
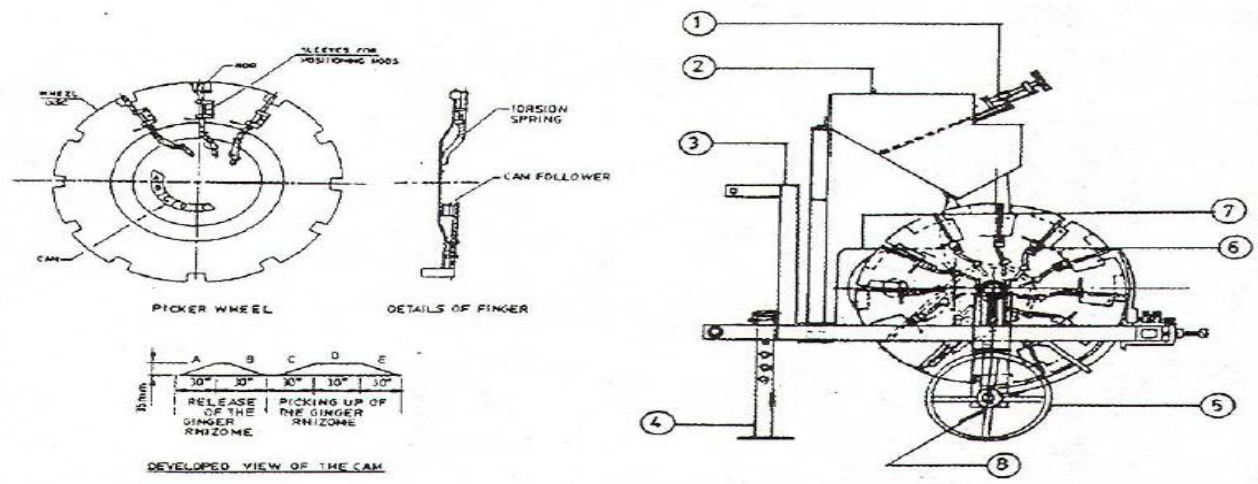

(1) Adjustable screw mechanism, (2) Hopper, (3) Main frame, (4) Stand,

(5) Ground wheel, (6) Picker wheel mechanism, (7) Electric motor, and (8) Chute.

Fig. 2: Schematics of picker wheel type metering mechanism mounted on test setup

Performance evaluation of vertical belt of paired row potato planter will also conducted at farmer's field covering approximately 117 ha. The results obtained were of similar pattern. Overall planting performance of the machine and potato crop stand will found to be satisfactory for the belt type paired row planter.

Chukwudi Muogbo (2019) The experiment will randomized in a factorial design of three planter levels of rhizome lengths (30, 45 and $60 \mathrm{~mm}$ ) and operational speeds of 8,10 , and $12 \mathrm{kmh}-1$. An average mass of $3 \mathrm{~kg}$ of wholesome turmeric rhizomes were introduced into the hopper of the planter and planted in $90 \mathrm{~m} 2$ of experimental plot. During field evaluation of the machine, the effective field capacity, field efficiency, missing index, multiple index and planting depth were considered; whereas laboratory tests were conducted to evaluate the planter's seed rate, percentage rhizome bruise wheel slippage and fuel consumption. Results obtained show that the maximum seed rate was 0.283 th- 1 . The maximum percent bruised turmeric rhizome will found to be 30.08 percent. The mean effective field capacity varied between 0.63 0.96 hah-1, at operational speeds of 8 and 12 kmh-1, respectively and $45 \mathrm{~mm}$ rhizome length. The mean field efficiency will obtained to be 65.8 percent. The maximum wheel slippage of 4.37 percent and fuel consumption of 3.8 lha- 1 were obtained at the machine speeds of $8 \mathrm{kmh}-1$ and $12 \mathrm{kmh}-1$, respectively; whereas the minimum wheel slippage of 3.14 percent and fuel consumption of 2.2 lha-1 were obtained at the machine speeds of $12 \mathrm{kmh}-1$ and $8 \mathrm{kmh}-1$, respectively for the range of the studied turmeric rhizome length. The highest and lowest percentage turmeric rhizome miss index of 35 percent were recorded for turmeric rhizome length of $30 \mathrm{~mm}$ at a speed of $10 \mathrm{kmh}-1$ and $8 \mathrm{kmh}-1$, respectively. An average planting depth of 68 $\mathrm{mm}$ will obtained. The numerical optimization approach will adopted to obtain an optimal operational parameters of $12 \mathrm{kmh}-1$ speed and $45 \mathrm{~mm}$ turmeric rhizome grading size with an overall desirability index of 0.73. An economic evaluation will calculated using the principle of payback period which will obtained to be very small (1.64 years) compared to the life of the planter of 17 years. Prospects for future works were suggested.

The turmeric planter has to be an automatic planting machine and they require firm, highquality, and uniform size of turmeric fingers; it seem to be a better option for most developing countries due to their ability to degrade, economy, and easy preparation and 
handling. However, suitable practices for the production of turmeric fingers with sufficient strength and durability matching the requirements of automated planting needs to be developed considering the agro-climatic conditions of the developing countries. A tractor-operated, low-cost, automatic planter with suitable feeding and planting units for turmeric fingers may be a better option for mechanizing transplanting operations in turmeric cultivation in small holdings. This will also meet the planting needs of other holdings where a small portion of land area is allocated for turmeric cultivation. Automatic planters offer many advantages but are complicated and expensive. In this regard, horticulturists, engineers, and manufacturers will need to collaborate to make automated mechanical planting an accepted practice In India, the gap between potentially achievable and actual yields range from 26 to $72 \%$ for Turmeric crops (Subramanian et al., 2000). This gap may be reduced by introduction of suitable turmeric planters and other improved crop cultivation practices that aid in precise placement of fingers with little or no planting shock to the fingers. This potential increase in yield can be significant considering that developing countries contribute to $72 \%$ of the worldwide turmeric production. While doing the research on such a type of turmeric planting and its methods is well furnished.

\section{References}

Abd El-Tawwab, I. M., Badaway, M. E. and El-Khawaga, S. 2007. Developing and performance evaluation of a locally fabricated sugar beet planter. Misr J. Ag.Eng. 24 (4): 648-665.

Ajav. E. A. and Ogunlade C. A. 2014. Physical properties of ginger (Zingiber officinale).Glob. J. Sci.Frontier Res. 14(8): 23-29.

Al-Gaadi, K. A. and Marey. 2011. Effect of forward speed and tuber characteristics on tuber spacing uniformity for a cup belt potato planter. Middle E.J.Sci.Res.8(4):753-758

Anonymous.2010. Report of MPUAT, Udaipur.

ASAE [American Society of Agricultural Engineers].1993.S358.2. Moisture measurement-for ages. St. Joseph, Mich.

Athmaselvi, K. A. and Varadharaju, N. 2002. Physical and thermal properties of turmeric rhizomes. Madras Agric. J. 89(10-12): 666-671.

Bjerkan, J. A. 1947. The precision planting equipments. J. Agric.Eng. 28(4):54-57.

Buitenwerf, H., Hoogmoed, W. B., Lerink, P., and Muller, J. 2006. Assessment of the behavior of potatoes in cup-beltplanter. Biosys.Eng.95(1): 35-41.

Chaudhuri, D. 2001. Performance evaluation of various types of furrow openers on seed drills-are view. J.Agric. Eng. Res. 79: 125-137

ollins, B. A and Fowler, D. B. 1996 Effects of soil characteristics depth, operating speed, and opener design on draft force during direct seeding. Soil and TillageRes.39: 199-211.

Dixit, A., Verma, A., Singh, A., and Manes, G. S. 2015. Performance of tractor mounted vertical belt paired row potato planter. Agric. Res. J. 52(1):5961.

Islam, F., Karim, M. R., Shahjahan, M., Hoque, M. O., Alam, M. R., and Hossain, M. A. 2002. Study on the effect of plant spacing on the production of turmeric at farmer's field. J. Plant Sci. 6: 616-617.

Kachman, S. D. and Smith, J. A. 1995. Alternative measures of accuracy in plant spacing for planters using single seed metering. Trans. of the ASAE, 38(2):379-387.

Krutz, G., Thompson, L., and Paul, C. 1984. Design of agricultural machinery. John 
Wiley and Sons. Singapore. pp 245255.

Mahender, B., Syam Sundar Reddy, P., Thanuja, S. G., Balakrishna, M. and Prathap, P. 2013. Effect of seed rhizome size and plant spacing on Growth, yield and quality of ginger (Zingiber officinale Rosc.) Under coconut cropping system. PlantArch. 15(2): 769-774.

Marey, S. A. 2015. Affecting each of ridger furrow opener parameters and planting methods on water use efficiency and sugar beet yield. Bulgarian J. Agric. Sci.21: 1304-1311.

Mari, G. R., Memon, S. A., Leghari, N., and Brohi, A. D. 2002. Evaluation of tractor operated potato planter. Pakistan J.Appl. Sci. 2(9): 889-891.

Mathanker S. K. and Mathew. M. 2002. Metering mechanisms for ginger planter. Agric.Eng.J. 11(1):31-39.

Mishra. A. K. and Kulkarni, S. D. 2009. Engineering properties of turmeric Rhizome(Curcuma Longa L).Agric. Eng. Today. 33(2): 26-31.

Monnaf, M. A., Rahim, M. A., Hossain, M. M. A., and Alam, M. S. 2010. Effect of planting method and rhizome size on the growth and yield of ginger. J.Agrofor.Environ.Sci. 4(2): 73-76.

Odigdoh, E. U. and Akubuo, C. O.1991.Atworow automatic mini set type planter. J.Agric. Eng.Res. 50:189-196.

Olojede, A. O., Nwokocha, C. C., Akinpelu, A. O., and Daltop, T. 2009. Effect of variety, rhizome and seed bed types on yield of turmeric (Curcuma longa L.) under a humid tropical agro-ecology.
Adv. Biol. Res. 3(1-2): 40-42

Panning, J. W., Kocher, M. F., Smith, J. A., and Kachman, S. D. 2000. Laboratory and field testing of seed spacing uniformity for sugar beet planters. Appl. Eng.Agric.16(1): 7-13.

RNAM. 1991. Agricultural machinery design data handbook, seeders and planter, Ec.and Soci. Commis. Asia and the Pacific: $17-20$.

Sahay, K. M. and Singh, K. K.1994.Unit operations of agricultural processing, Vikas Publishing House Pvt.Ltd, New Delhi.

Singh, A. and Kaur, S. 2015. Evaluation of different methods of turmeric (Curcuma longa L.) plantation.Int.J. Agric.Sci. 11(1): 201-203.

Singh, R. D. 2004. Tractor mounted semiautomatic two row belt type potato planter ridger.Agric. Eng. Today.28(5 \& 6):69-74.

Subhashini. S., Ananda kumar, S., and Niveadhitha, S. 2015.To study the physical properties of turmeric rhizomes at different moisture content. Indian J. Appl.Res.5(6): 501-504.

Vasuki, G. 2012. Design and development of a tractor operated Turmeric planter. Unpublished M. Tech. (Agri. Eng.) Thesis, department of farm machinery, Agricultural Engineering College and Research Institute Tamil Nadu Agricultural University, Coimbatore.

Wanjura, D. F and Hudspeth, E. B. 1968. Metering and pattern characteristic of a horizontal edge drop plate planter. Trans of the ASAE. 11(4): 468-469.

\section{How to cite this article:}

Nimbalkar, D. V. and Nalawade, S. M. 2021. A Review Paper on Development and Standardization of Metering Mechanism for Automatic Turmeric Planter. Int.J.Curr.Microbiol.App.Sci. 10(05): 680-694. doi: https://doi.org/10.20546/ijcmas.2021.1005.076 